\title{
ANALYZE ONE OF THE CAUSES OF THE BAD KNOWLEDGE OF CZECH PUPILS
}

\author{
Jaroslav Š́́PAL
}

\begin{abstract}
The paper presents views on the assessment of knowledge the pupils and students tested way. Author proves that if the student chooses from four offered one correct answer, so this method will always be a certain number of students have successfully passed the tests without anything learned. The author believes that it is necessary to restrict testing. The greatest attention should be paid to the practical computation examples, analyzes of problems and finding a logical solution procedure. The author would like produced an open discussion on this topic.
\end{abstract}

Key words: the Test, PISA, OECD

\section{ANALÝZA JEDNÉ Z PŘÍČIN ŠPATNÝCH ZNALOSTÍ}

Resumé: Příspěvek uvádí názor na hodnocení znalostí žáků a studentů způsobem testování. Autor dokazuje, že výběr jedné správné odpovědi ze čtyř nabídnutých odpovědí umožní vždy určitému počtu studentů projít úspěšně testy, aniž by se cokoliv naučili. Autor se domnívá, že je potřeba omezit přezkušování pomocí testů. Největší pozornost je třeba věnovat praktickému počítání př́kladů, rozborům úloh a hledání logického postupu řešení. Autor by rád vyvolal otevřenou diskuzi na toto téma.

\section{Klíčová slova: testy, PISA, OECD}

\section{1 Úvod}

Výsledkem je stav, že technické školy, kde matematika, fyzika a chemie je základním předpokladem pro studium, trpí nedostatkem kvalitních studentů. Průmyslové podniky pak nemají dostatek technicky vzdělaných odborníků. Tento stav je pro českou společnost neutěšený, a pokud ho chceme napravit, je potřeba hledat jeho příčiny a začít je napravovat. Domnívám se, že významný vliv však má i způsob přezkušování znalostí pomocí testů, který se rozšíríl především $\mathrm{v}$ posledních letech.

Podle ředitelky základni školy Mendelova Martiny Thumsové je jedním z důvodì špatných výsledki $i$ způsob učení. „Hrobem napríklad pro češtinu i matematiku jsou predtištěné pracovni sešity, do nichž děti jen doplňuji i/y, s/z, vprípadě matematiky doplñuji čislo do predtištěné odpovédi, výsledky do sestaveného príkladu," mini ředitelka. Špatná je také pracovni morálka školákì. „,Velké množství dětí nenosi domácí úkoly, neprocvičuji učivo. Jenom ve škole se to však nenaučí. Např́klad pravopis si musi ditě zautomatizovat častým cvičením. " [3]

$\mathrm{V}$ poslední době se rozšírílo na základních a středních školách přezkušování znalostí pomocí testů, kdy žák vybírá z nabízených odpovědí jednu správnou. Nespornou výhodou testů pro učitele je velmi rychlé a snadné provedení oprav a oznámkování. Zejména pokud se testy vyplňují přímo $\mathrm{v}$ počítači, je možné konstatovat, že učitel nemá s opravováním vůbec žádnou práci.

Způsob ověrování znalostí testy není ve své podstatě špatný, nesmí se to ovšem, jako u všeho, přehánět. Žáci se musí naučit vyjádřit i písemnou formou. U exaktních předmětů, zejména matematiky, fyziky a chemie, které kromě řešení př́kladů učí žáky a studenty i logickému myšlení, se výsledky přezkušování pouze testy projeví tím, že žáci i studenti neumí vyřešit konkrétní zadané př́klady. Bohužel, díky nízké čtenářské gramotnosti, často žáci a studenti nechápou zadání př́ikladu.

Testování poskytne srovnání znalostí mezi jednotlivými výukovými institucemi, avšak nemůže vypovídat o získaných znalostech jednotlivých žáků a význam testů pro ověření hloubky a rozsahu získaných znalostí je prakticky nulový

\section{Vliv přezkušování testy na znalosti studentů}

Přezkušování znalostí $\mathrm{v}$ matematice probíhá $\mathrm{v}$ posledních letech velmi často pomocí testů. Student vybírá ze čtyř nabídnutých odpovědí jednu správnou. Takový způsob testování přináší pro učitele jednodušší způsob opravování, obzvlášt' v prípadě, když jsou testy vypracovávány pomocí počítačů. $\mathrm{Na}$ základě 
zákonů pravděpodobnosti je však možné tvrdit, že určitý počet studentů projde úspěšně testy, aniž by se cokoliv naučili.

Di̊kaz tohoto tvrzení provedeme na následujícím príkladu, kdy test provádí skupina studentů, kteří se vůbec nepřipravovali a odpovědi budou zaškrtávat náhodně. Pravděpodobnost úspěchu vyjádřená relativním číslem se vypočítá podle následujícího vzorce:

$$
\delta=1-\sum_{i=0}^{x-1}\left\{\left(\begin{array}{l}
\mathrm{a} \\
\mathrm{i}
\end{array}\right) *\left(\frac{1}{\mathrm{~b}}\right)^{\mathrm{i}} *\left(1-\frac{1}{\mathrm{~b}}\right)^{\mathrm{a}-\mathrm{i}}\right\}
$$

kde:

$$
\begin{array}{ll}
\text { a } & \text { počet otázek v testu } \\
\text { b } & \text { počet nabízených odpovědí } \\
\text { x } & \text { počet úspěšných odpovědí }
\end{array}
$$

Test ohodnocený známkou čtyři - vyhovující má obvykle $30 \%$ správných odpovědí, proto budou hledány pravděpodobnosti s $30 \%$ a více správnými odpověd'mi. Čím více bude $\mathrm{v}$ testu otázek, tím se procento úspěšnosti mírně snižuje.

\section{Test se šesti otázkami}

Test se šesti otázkami, který má být ohodnocený známkou čtyři - vyhovující, musí mít 2 správné odpovědí.

$$
\begin{gathered}
\delta=1-\sum_{i=0}^{2-1}\left\{\left(\begin{array}{l}
6 \\
\mathrm{i}
\end{array}\right) *\left(\frac{1}{4}\right)^{\mathrm{i}} *\left(1-\frac{1}{4}\right)^{6-\mathrm{i}}\right\} \\
\delta=0,466
\end{gathered}
$$

Pro dosažení výsledku uspěl v testu se šesti otázkami je procento úspěšnosti $46,6 \%$. To znamená, že ze stovky studentů jich čtyřicet sedm uspěje, aniž by se věnovalo přípravě.

\section{Test s devíti otázkami}

Test s devíti otázkami, který má být ohodnocený známkou čtyřri - vyhovující, musí mít 3 správné odpovědí.

$$
\begin{gathered}
\delta=1-\sum_{i=0}^{3-1}\left\{\left(\begin{array}{l}
9 \\
\mathrm{i}
\end{array}\right) *\left(\frac{1}{4}\right)^{\mathrm{i}} *\left(1-\frac{1}{4}\right)^{9-\mathrm{i}}\right\} \\
\delta=0,399
\end{gathered}
$$

Pro dosažení výsledku uspěl $\mathrm{v}$ testu $\mathrm{s}$ devíti otázkami je procento úspěšnosti $39,9 \%$. To znamená, že ze stovky studentů jich čtyřicet uspěje, aniž by se věnovalo př́pravě.

\section{Test s osmnácti otázkami}

Test s osmnácti otázkami, který má být ohodnocený známkou čtyři - vyhovující, musí mít 6 správné odpovědí.

$$
\begin{gathered}
\delta=1-\sum_{i=0}^{6-1}\left\{\left(\begin{array}{c}
18 \\
\mathrm{i}
\end{array}\right) *\left(\frac{1}{4}\right)^{\mathrm{i}} *\left(1-\frac{1}{4}\right)^{18-\mathrm{i}}\right\} \\
\delta=0,283
\end{gathered}
$$

Pro dosažení výsledku uspěl $\mathrm{v}$ testu s osmnácti otázkami je procento úspěšnosti $28,3 \%$. To znamená, že ze stovky studentů jich dvacet osm uspěje, aniž by se věnovalo prípravě.

\section{Test se dvaceti čtyřmi otázkami}

Test se dvaceti čtyřmi otázkami, který má být ohodnocený známkou čtyři - vyhovující, musí mít 8 správných odpovědí.

$$
\begin{gathered}
\delta=1-\sum_{i=0}^{8-1}\left\{\left(\begin{array}{c}
24 \\
\mathrm{i}
\end{array}\right) *\left(\frac{1}{4}\right)^{\mathrm{i}} *\left(1-\frac{1}{4}\right)^{24-\mathrm{i}}\right\} \\
\delta=0,233
\end{gathered}
$$

Pro dosažení výsledku uspěl v testu se dvaceti čtyřmi otázkami je procento úspěšnosti $23,3 \%$. To znamená, že ze stovky studentů jich dvacet tři uspěje, aniž by se věnovalo přípravě.

Testy s větším počtem otázek jsou již časově nezvládnutelné. Pokud by na každou otázku $\mathrm{v}$ testu bylo plánováno 5 minut, potom test s 18 otázkami by trval 90 minut a test se 24 otázkami 120 minut.

\section{Grafické znázornění průběhů}

Průběh pravděpodobností uvedených prrípadů je znázorněn na obrázku č. 1 , kde na ose $\mathrm{x}$ je znázorněn počet správných odpovědí a na ose y je pravděpodobnost dosažení počtu správných odpovědí. 


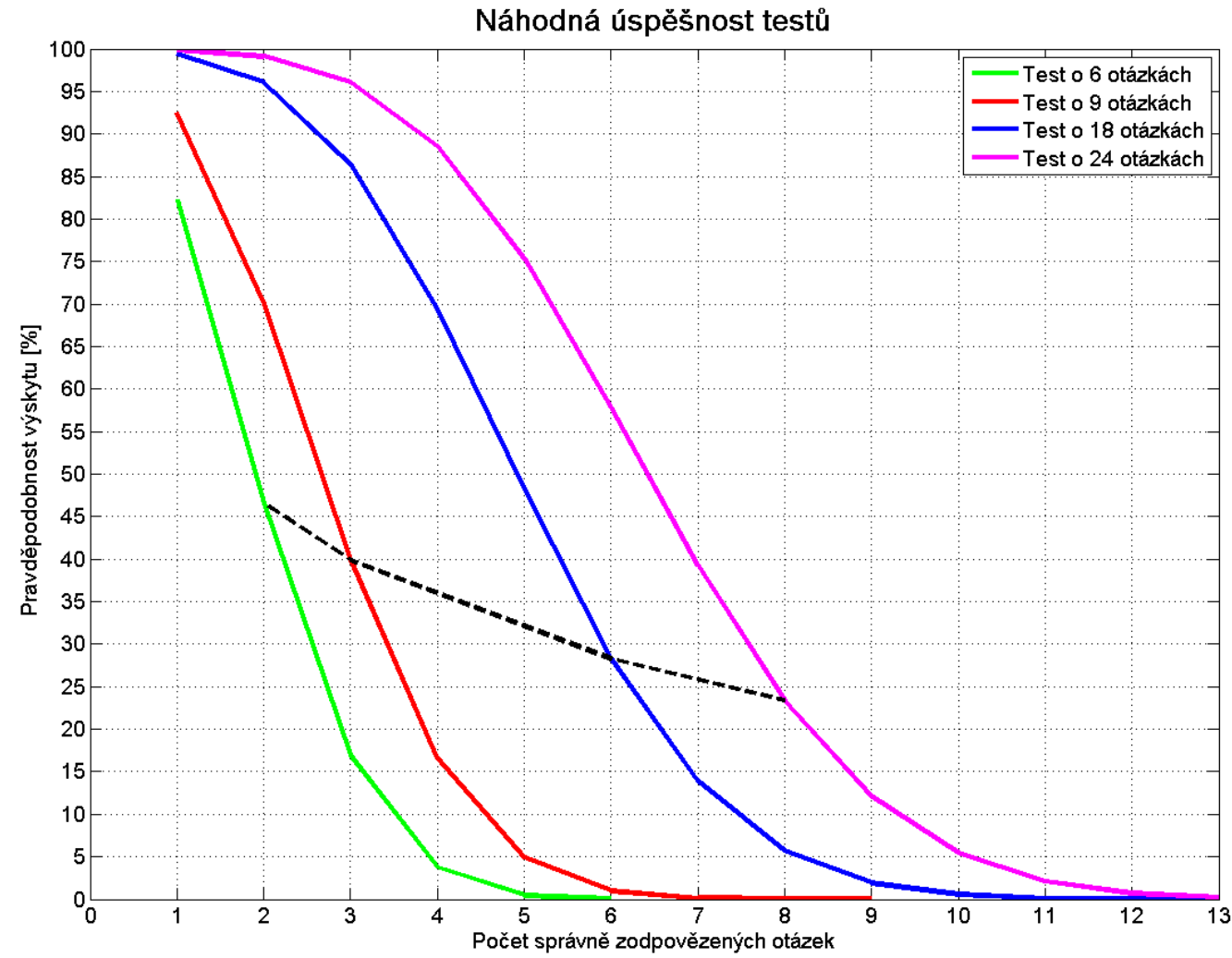

Obr. 1: Porovnání průběhủ úspěšnosti testů

Černá čárkovaná čára spojuje body jednotlivých grafů, kdy je v testu 30 \% správných odpovědí.

\section{Pedagogický experiment}

Pro potvrzení výše uvedených tvrzení byl vypracován experiment. Bylo vybráno náhodně deset respondentů, kteří vyplňovali testy anonymně. Aby respondenti nemohli používat své empirické znalosti, byly pripraveny „prázdné“ zkušební testy, viz následující př́íklad:
1. Otázka-odpověd': A $\mathrm{B} \quad \mathrm{C} \quad \mathrm{D}$
2. Otázka-odpověd': A $\mathrm{B} \quad \mathrm{C} \quad \mathrm{D}$
3. atd

Před zahájením vyplňování testů, byly náhodným způsobem vybrány správné odpovědi. Respondenti byli nuceni vyplňovat své odpovědi naprosto náhodně. Hodnocení bylo prováděno pouze na základě $30 \%$ úspěšnosti. To znamená, že kdo dosáhl třetiny a více správných odpovědí jeho znalosti byly uznány jako vyhovující. Vyhodnocení testů přineslo následující výsledky, obrázek č. 2. Test se šesti otázkami dopadl tak, že v první testu byli úspěšní 4 respondenti, tj. $40 \%$ a $\mathrm{v}$ dalších dvou testech bylo úspěšných 5 respondentů.

V testech s devíti otázkami byli úspěšní 2; 4 a 7 respondentů. Pokud bude spočten průměr, tak se jedná o 4,3 respondenty, což je 43,3\%.

V testech se osmnácti otázkami byli úspěšní $2 ; 4$ a 5 respondentů. Pokud bude spočten průměr, tak se jedná o 3,7 respondenty, což je $36,7 \%$.

$\mathrm{V}$ testech se dvaceti čtyřmi otázkami byli úspěšní 2; 2 a 6 respondentů. Pokud bude spočten průměr, tak se jedná o 3,3 respondenty, což je $33,3 \%$. 


\begin{tabular}{|c|c|c|c|c|c|c|c|c|c|c|}
\hline \multicolumn{10}{|c|}{ Sest otázek v testu } \\
\hline 1. res. & 2. res. & 3. res. & 4. res. & 5. res. & 6. res. & 7. res. & 8. res. & 9. res. & 10. res. & Vyhověl \\
\hline 1 & 1 & 1 & 1 & 2 & 2 & 1 & 3 & 3 & 1 & $\mathbf{4 0 \%}$ \\
\hline 4 & 2 & 1 & 2 & 1 & 1 & 2 & 0 & 1 & 5 & $\mathbf{5 0 \%}$ \\
\hline 2 & 4 & 1 & 3 & 3 & 1 & 2 & 1 & 1 & 4 & $\mathbf{5 0 \%}$ \\
\hline
\end{tabular}

\begin{tabular}{|c|c|c|c|c|c|c|c|c|c|c|}
\hline \multicolumn{10}{|c|}{ Devět otázek v testu } \\
\hline 1. res. & 2. res. & 3. res. & 4. res. & 5. res. & 6. res. & 7. res. & 8. res. & 9. res. & 10. res. & Vyhověl \\
\hline 1 & 1 & 1 & 1 & 2 & 2 & 1 & 3 & 4 & 1 & $\mathbf{2 0 \%}$ \\
\hline 6 & 2 & 1 & 3 & 2 & 2 & 2 & 0 & 4 & 5 & $\mathbf{4 0 \%}$ \\
\hline 3 & 6 & 2 & 3 & 3 & 4 & 3 & 3 & 2 & 5 & $\mathbf{7 0 \%}$ \\
\hline
\end{tabular}

\begin{tabular}{|c|c|c|c|c|c|c|c|c|c|c|}
\hline \multicolumn{10}{|c|}{ Osmnáct otázek v testu } \\
\hline 1. res. & 2. res. & 3. res. & 4. res. & 5. res. & 6. res. & 7. res. & 8. res. & 9. res. & 10. res. & Vyhověl \\
\hline 5 & 4 & 4 & 3 & 4 & 3 & 5 & 7 & 7 & 3 & $\mathbf{2 0 \%}$ \\
\hline 7 & 3 & 5 & 5 & 3 & 6 & 4 & 2 & 6 & 6 & $\mathbf{4 0 \%}$ \\
\hline 9 & 6 & 4 & 8 & 5 & 5 & 7 & 5 & 5 & 7 & $\mathbf{5 0 \%}$ \\
\hline
\end{tabular}

\begin{tabular}{|c|c|c|c|c|c|c|c|c|c|c|}
\hline \multicolumn{10}{|c|}{ Dvacet čtyři otázek v testu } \\
\hline 1. res. & 2. res. & 3. res. & 4. res. & 5. res. & 6. res. & 7. res. & 8. res. & 9. res. & 10. res. & Vyhověl \\
\hline 8 & 6 & 4 & 4 & 4 & 7 & 6 & 7 & 10 & 6 & $\mathbf{2 0 \%}$ \\
\hline 9 & 5 & 6 & 8 & 5 & 6 & 5 & 3 & 7 & 6 & $\mathbf{2 0 \%}$ \\
\hline 11 & 8 & 7 & 11 & 8 & 6 & 9 & 6 & 7 & 9 & $\mathbf{6 0 \%}$ \\
\hline
\end{tabular}

Obr. 2: Tabulkové zpracování výsledků testi̊

\section{Závěr}

Praktický experiment potvrdil výsledky teoretických úvah. Z deseti respondentů, kteři pouze správné odpovědi hádali, vždy určitý počet vyhověl. Výsledky skutečných testů při hodnocení výuky dopadnou mnohem lépe, protože žák nebo student, který při výkladu látky trochu dával pozor a nebo si před testem zkoušenou látku jenom prolistoval, již nemůže být zařazen $\mathrm{v}$ kategorii úplných laiků.

Z uvedeného rozboru vyplývá, že použivání testů, kdy student vybírá ze čtyř nabídnutých odpovědí jednu správnou, umožní vždy určitému počtu studentů projít úspěšně testy, aniž by se cokoliv naučili.

Je tedy potřeba omezit přezkušování pomocí testů ve výuce $\mathrm{i}$ omezit $\mathrm{v}$ současné době tak moderní pracovní sešity a vrátit se praktickému počítání př́kladů, rozborům úloh a hledání logického postupu řešení. Výuka českého jazyka by se měla vrátit ke čtení, psaní slohů, rozborům textů i $\mathrm{k}$ tak neoblíbeným diktátům. Těmto metodám výuky je nutné věnovat největší pozornost, aby vzdělanost žáků a studentů dále neklesala, ale naopak rostla.
Výsledkem toho, že v současné době ve výuce převládá doplňování a testování je stav, že technické školy, kde matematika, fyzika a chemie jsou základním předpokladem pro studium, trpí nedostatkem kvalitních studentů. Průmyslové podniky pak nemají dostatek technicky vzdělaných odborníků. Tento stav je pro českou společnost neutěšený, a pokud ho chceme napravit, je potřeba hledat jeho příčiny a začít je napravovat.

\section{Literatura}

[1] Dostupné z: http://link.springer.com/article/ 10.2478\%2Fs13374-012-0004-5\#page-1

[2]

Dostupné z: http://www.pisa2012.cz/?a=harmonogram

[3] Dostupné z: http://zpravy.idnes.cz/zacinerozumi-textum-a-neumi-myslet-matematickyzmenit-to-ma-prirucka

Doc. Ing. Jaroslav Š́pal Ph.D.

Katedra energetiky a elektrotechniky

FVTM UJEP; Pausterova 1; 400 96, Ústí n. L.,

ČR; Tel: +420 475285 515;

E-mail: sipal@fvtm.ujep.cz;

Www pracoviště: www.fvtm.ujep.cz 